\title{
Biomineralization of charophytes and their application in arsenic removal from aquatic environment
}

\author{
S. Amirnia, T. Asaeda \& C. Takeuchi \\ Department of Environmental Science, Saitama University, Saitama, Japan
}

\begin{abstract}
As(III) is present in neutral form $\left(\mathrm{H}_{3} \mathrm{AsO}_{3}^{0}\right)$ at the $\mathrm{pH}$ ranges of natural waters; therefore, sorption and biosorption are not much effective removal methods for dissolved arsenic. In this study, we investigated the biomineralization of charophyte $C$. braunii in $\mathrm{Ca}$ and $\mathrm{Mn}$-containing media and its potential for remediation of As(III) in aquatic environments. Relative proportions of the arsenic adsorbed in the plant biomass and those incorporated into calcium and manganese deposits were discerned using a modified sequential extraction. Under favorable conditions, over $50 \%$ of the accumulated arsenic by the plant was Mn-bound.
\end{abstract}

\section{INTRODUCTION}

Arsenic is a notorious metalloid for its adverse effects on human and environmental health. From As(III) and $\mathrm{As}(\mathrm{V})$, arsenite (As(III)) is more toxic and more difficult to be removed from water due to its neutral charge in natural water pHs (Vaclavikova et al., 2008).

Charophytes, common submerged plants in freshwaters, are known for their ability to form calcite encrustation and contribute to nutrient cycling, such as phosphorous, in water columns (Asaeda et al., 2014; Kufel et al., 2016). They are also useful for remediation of various pollutants, such as chromium and cadmium from contaminated waters (Gomes \& Asaeda, 2013).

Calcite encrustation in Chara, genera of charophytes, is known to be inevitable due to bicarbonate assimilation and as a by-product of photosynthetic activity of the plants (McConnaughey, 1991). In this work, we reported formation of a secondary type of biogenic deposits on the cell walls of calcifying charophyte, Chara braunii (common to rice fields) in $\mathrm{Ca} / \mathrm{Mn}$-containing media, and our objective was to assess the capability of the plant to accumulate arsenic in the context of charophytes biomineralization.

\section{METHODS/EXPERIMENTAL}

We examined As(III) accumulation in calcifying charophyte Chara braunii in a laboratory experiment for 4 weeks. Experimental plants were placed in a temperature-controlled incubator at $20 \pm 2^{\circ} \mathrm{C}$ with $12 \mathrm{~h}: 12 \mathrm{~h}$ light: dark photoperiod.

The plant growth in the presence of $0.5 \mathrm{mg} \mathrm{As} \mathrm{L}^{-1}$, and varying concentrations of $\mathrm{Mn}$ (II) and $\mathrm{Ca}(\mathrm{II})$ was tested, and shoot elongation, as a parameter for the growth, was calculated relative to the initial length of the plants. Chlorophyll Florescence parameters $\left(\mathrm{F}_{\mathrm{v}} / \mathrm{F}_{\mathrm{m}}\right)$ were analyzed by an auto imager (Olympus
Tokyo) after a $20 \mathrm{~min}$ of dark adaptation. Element concentrations in water samples were measured by an ICP-OES (Optima 5300 DV).

The extent of arsenic storage in the plant biomass and of that trapped on biomineral deposits on the plant by a modified chemical fractionation method. Scanning electron microscopy (Hitachi S-3400N) was employed to study the plant surface morphology and encrustations.

\section{RESULTS AND DISCUSSION}

Temporal variation of shoot length of $C$. braunii showed an average decrease of $\sim 48 \%$ in one week and $\sim 16 \%$ in four weeks indicating adaptation of the plants to the new environment. Plants exposed to arsenic exhibited some reduction of chloroplast resulting in chlorosis. However, since the arsenic level was the same in all the studied experimental units, no significant differences was found between the treatments for $\mathrm{F}_{\mathrm{v}} / \mathrm{F}_{\mathrm{m}}$ values $(\mathrm{P}>0.05)$.

SEM analyses helped us to identify the formation of volcano shaped deposits with diameters of $5-10 \mu \mathrm{m}$ on the plant internodal cells and branchlets (Fig. 1). EDX (energy dispersive X-ray) elemental mapping revealed that the main metal constituent of these unique deposits is manganese $\left(\mathrm{MnO}_{x}\right)$, which was formed in the presence of manganese in the nutrient culture.

Figure 2 shows the relative proportions of the arsenic adsorbed in the plant biomass and those incorporated into calcium and manganese deposits determined by a modified sequential extraction method. Following the exchangeable fraction, the manganese deposits retained a major fraction of the arsenic, while the Ca-bound together with the residual/organicbound arsenic were the least dominant fractions. 


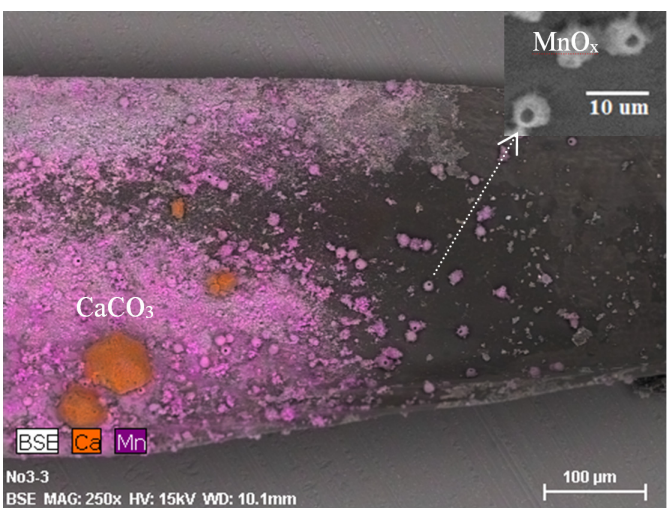

Figure 1. SEM-EDX micrograph of $C$. barunii internodal cell wall surface. $\mathrm{CaCO}_{3}$ and volcano-shaped deposits of $\mathrm{MnO}_{\mathrm{x}}$ were formed on the plant.

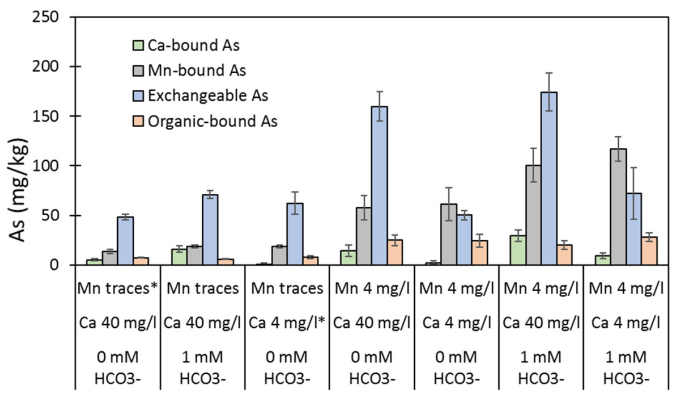

Figure 2. As concentration $\left(\mathrm{mg} \mathrm{kg}^{-1} \mathrm{DW}\right)$ and relative distribution within each chemical fraction of the plant. As concentration in all treatment were $0.5 \mathrm{mg} \mathrm{L}^{-1}\left(*=4 \mathrm{mg} \mathrm{L}^{-1}\right.$ $\mathrm{Ca}$ and also trace $\mathrm{Mn}$ levels in water were due to mixing with substrate and were not added).

The amount of arsenic associated with $\mathrm{Ca}$ and organic were found little $\left(1.0-29.5 \mathrm{mg} \mathrm{kg}^{-1}\right.$ for $\mathrm{Ca}-$ bound, and $7.3-28.3 \mathrm{mg} \mathrm{kg}^{-1}$ for residual/organicbound, respectively). Arsenic percentages associated to organic fraction were the lowest among all the studied fractions.

As depicted in Figure 2, over $50 \%$ of the total As in C. braunii was present in Mn-oxides phase in the assay with low calcium and high level of $\mathrm{Mn}$ in water in the presence of bicarbonate. The manganese oxide bound arsenic had an increasing trend with increase in $\mathrm{Mn}$ concentration with bicarbonate ions in water and reached its highest value $\left(\sim 120 \mathrm{mg} \mathrm{kg}^{-1}\right)$ in the treatment with $4 \mathrm{mg} \mathrm{Mn} \mathrm{L}^{-1}, 40 \mathrm{mg} \mathrm{Ca} \mathrm{L}^{-1}$ with addition of bicarbonate compared to the other conditions.

Mechanism of arsenic bound to calcite and $\mathrm{MnO}_{x}$ deposits, and chemical nature of As-Mn and As-Ca complexes are still a matter of debate. As(III) might have reacted with solid-state Mn-oxide as electron acceptor, and might have oxidized As(III) in solution to $\mathrm{As}(\mathrm{V})$, with or without disproportionation. Oxidation of $\mathrm{As}(\mathrm{III})$ by manganese oxide followed by co-precipitation/adsorption of $\mathrm{As}(\mathrm{V})$ with manganese oxide on the cell walls of $C$. braunii was likely to be the mechanism for arsenic removal.

\section{CONCLUSIONS}

Appearance of two types of biominerals on the surface of charophyte $C$. braunii, which were mediated by simultaneous presence of $\mathrm{Ca}$ and $\mathrm{Mn}$ in the culture medium, promoted the arsenic accumulation capacity of the plant. Arsenic partitioned differently amongst the two deposits, and $\mathrm{MnO}_{\mathrm{x}}$ retained a larger amount of the arsenic removed by the plant as compared to calcite deposits in all water conditions in this work. The portion of arsenic co-precipitated and trapped during the calcite encrustation and $\mathrm{MnO}_{\mathrm{x}}$ formation processes may not leach back easily to water upon plants' senescence and decay.

\section{ACKNOWLEDGEMENTS}

This work was supported by JSPS KAKENHI Grant Number 16F16750.

\section{REFERENCES}

Gomes, P.I.A. \& Asaeda, T. 2013. Phytoremediation of heavy metals by calcifying macro-algae (Nitella pseudoflabellata): implications of redox insensitive end products. Chemosphere 92(10): 1328-1334.

McConnaughey, T. 1991. Calcification in Chara corallina: $\mathrm{CO}_{2}$ hydroxylation generates protons for bicarbonate assimilation. Limnol. Oceanogr. 36(4): 619-628.

Kufel, L., Strzałek, M. \& Biardzka, E. 2016. Site- and speciesspecific contribution of charophytes to calcium and phosphorus cycling in lakes. Hydrobiologia 767(1): 185-195.

Vaclavikova, M., Gallios, G.P., Hredzak, S. \& Jakabsky, S. 2008. Removal of arsenic from water streams: an overview of available techniques. Clean Technol. Environ. Policy. 10(1): 89-95. 